\title{
Effects of Surveying for the Federally Endangered Spruce-fir Moss Spider (Microhexura montivaga Crosby \& Bishop) on its Bryophyte Habitat
}

\author{
Corinne A. Diggins ${ }^{1, *}$ and W. Mark Ford ${ }^{2}$
}

\begin{abstract}
Microhexura montivaga (Spruce-fir Moss Spider) is a federally endangered arachnid endemic to high-elevation montane conifer forests of the southern Appalachian Mountains. The spider is cryptic and difficult to monitor because this species lives in the interface between the bryophyte mat and the rock surface. Since temporary removal of the bryophyte mat is necessary to monitor the spider, surveyors may negatively impact the spider's habitat during monitoring. To help inform survey protocol for this endangered species, we studied reattachment rates of bryophyte mats to rock surfaces after their removal. In 2017, we surveyed sixty $10 \mathrm{~cm}$ x $10 \mathrm{~cm}$ plots, assigning a plot to either control or treatment (i.e., application of water post-reattachment). We monitored plots for 1 year post-survey to determine reattachment rates. The majority of plots $(70 \%)$ reestablished after 1 year, whereas $15 \%$ did not reattach or showed substantial prolonged (e.g., $\sim 1$ year) desiccation and $15 \%$ completely fell off or had $100 \%$ prolonged desiccation and were chlorotic. We found that mat depth and overstory canopy cover had no effect on mat reestablishment, although bryophyte type did. We found no difference between treatment and control plots, suggesting that no treatment is needed for mats to reestablish under the conditions described. Rock slope significantly influenced reestablishment rates, highlighting that surveying bryophyte mats on slopes $>80 \%$ may diminish or destroy habitat. Further research is needed to determine long-term monitoring effects on the spider and its habitat, especially in relation to disturbance regimes and ecological restoration of Picea rubens (Red Spruce).
\end{abstract}

\section{Introduction}

Effective monitoring of an endangered species is necessary not only for assessing populations, but also to understand mechanisms that may influence populations and impact the long-term persistence of the species (Campbell et al. 2002). However, endangered species are inherently difficult to monitor due to small population sizes, narrow habitat requirements, and small geographic ranges, and further challenges occur if the species is small-bodied and cryptic in nature (Diggins et al. 2016, Dillard et al. 2008, Edworthy et al. 2012, Rabinowitz et al. 1986). The Endangered Species Act (ESA) of 1973 (16 U.S.C. $\S \S 1531-1544$ [1988]) requires the use of "the best scientific and commercial data available" (Section 7[a][2]). In order to assess recovery efforts within critical habitat and meet the legal requirements for recovery plans, it is crucial to develop a monitoring protocol that will allow for the assessment of population size, habitat occupancy, distribution, and habitat condition over

\footnotetext{
${ }^{1}$ Department of Fish and Wildlife Conservation, Virginia Tech, Blacksburg, VA 24061. ${ }^{2}$ US Geological Survey, Virginia Cooperative Fish and Wildlife Research Unit, Blacksburg, VA 24061. Corresponding author - cordie1@vt.edu.
}

Manuscript Editor: Foster Levy 
time for endangered species (Barata et al. 2017, Campbell et al. 2002, Schori et al. 2020, Smallwood et al. 1999).

Microhexura montivaga Crosby \& Bishop (Spruce-fir Moss Spider) is a small $(0.25-0.40 \mathrm{~cm})$ mygalomorph spider and is one of 4 arachnids listed as endangered under the Endangered Species Act (Fridell 1995). The spider is endemic to montane sky islands of Picea rubens Sarg. (Red Spruce)-Abies fraseri (Pursh) Poi (Fraser Fir) forests (hereafter spruce-fir) in the southern Appalachian Mountains of North Carolina, Tennessee, and Virginia (Coyle 1981, 1997; USFWS 2001) and occurs in 6 disjunct sky island populations (Coyle et al. 2009, Hedin et al. 2015, USFWS 2001). The spider's habitat is considered one of the most endangered forested ecosystems in the United States (Noss et al. 1995) due to industrial logging, atmospheric acid deposition, anthropogenic climate change, and introduced forest pests such as Adelges piceae Ratzeberg (Balsam Woolly Adelgid [BWA]) (Dull et al. 1988, Eagar and Adams 1992, Koo et al. 2015, Korstian 1937, Walter et al. 2017, White et al. 2014). However, some forest recovery from acid deposition occurred after the passing of the 1980 Clean Air Act (Banks 2013, Kaylor et al. 2017, Mathias and Thomas 2018).

Designated critical habitat for the spider is defined as well-drained epilithic bryophyte mats growing on north-facing, emergent rock outcrops, colluvial boulders, and cliffs under dense canopies of spruce-fir forests (Coyle 1997, 2009; USFWS 2001). Bryophyte mats provide relatively stable microclimates compared to ambient temperatures, although moisture in the mats varies with relative humidity (Seaborne and Catley 2016). The largest threat to the spider is habitat loss through bryophyte desiccation and disturbance. Past population declines were observed in the 1980s at several sites due to desiccation events caused by drought and overstory canopy dieback from BWA (Coyle 2004, 2009). Since spiders are distributed in highly disjunct areas, sometimes less than a few acres in size, overstory disturbance can lead to desiccation events that may impact an entire population (USFWS 2001).

Bryophytes adapted to highly shaded, humid environments are sensitive to desiccation due to changes in microclimate moisture caused by loss of overstory cover (Nelson and Halpern 2005, Proctor 2000). Loss in overstory spruce-fir in the southern Appalachians is associated with natural disturbances such as wind-throw events and ice damage, as well as disturbances from BWA infestations and spruce decline (Kaylor et al. 2017, Nicholas and Zedaker 1989, Rentch et al. 2010, Smith and Nicholas 1998, White et al. 1985). Reduction of overstory canopy cover can alter under-canopy climatic conditions within forests by increasing temperature and light while decreasing humidity, which may influence bryophyte species composition (Halpern et al. 2014, Nelson and Halpern 2005, Stehn et al. 2010a). Epilithic bryophytes generally lack a non-bryophyte substrate (e.g., humus, soil) to hold moisture and are poikilohydric, resulting in potential fluctuations between insufficient and excessive moisture (Glime 2017, Norris 1974), which may make them sensitive to changes in under-canopy climatic conditions. Southern Appalachian spruce-fir forests are immersed in low clouds for a significant proportion of the year (Berry and Smith 2012, 2013; Horton and Culatta 2016), thereby providing moist 
conditions for bryophytes in this system (Norris 1974). However, Richardson et al. (2003) observed that cloud ceiling height has increased in recent years in the eastern United States, possibly due to climate change. Rising cloud ceilings may impact under-canopy climatic conditions, plant physiology, and species distribution within spruce-fir forests (Berry and Smith 2013, Culatta and Horton 2014, Johnson and Smith 2008, Ulrey et al. 2016).

The Spruce-fir Moss Spider is inherently difficult to study because it resides between the interface of bryophyte mats and the rock outcrops that provide the mat substrate. Due to the spider's endangered status, there are restrictions on incidental take (ESA, Section 9). Specimens of Spruce-fir Moss Spider are observed in situ without specimen collection. Survey techniques typically used to confirm the presence of other microinvertebrates from bryophyte mats result in specimen collection (e.g., Andrew et al. 2003, Lindo and Winchester 2013, Wehner et al. 2018, Yanoviak et al. 2007) and would not be appropriate when surveying for the Sprucefir Moss Spider. However, determining the spider's presence requires potentially destroying its habitat by physically removing portions of the bryophyte mat from the rock. Replacement of the mat does not assure the bryophytes' reattachment and survival (Coyle 1997, 1999). Removal of the bryophyte mats during surveys could lead to mat loss, damage, or desiccation, evidence of which can be found at previously surveyed sites (Coyle 2004, Roble 2012). Bryophyte recovery may be slow after surveys, and previous recommendations stated that surveys should not occur frequently (Coyle 1999), although recommended duration between surveys was never specified.

Due to continued threats to the spider's habitat, developing a monitoring plan is critical to assessing the spider's populations and distribution across its range. Although range-wide surveys of the spider have occurred (Coyle 1997, 1999, 2004, 2009; Harp 1991, 1992), a standardized long-term monitoring program has yet to be established. Currently, no specific protocol is in place to reduce potential effects of surveys, such as minimum time between surveys reoccurring in the same spot, and no study has quantified survey effects on habitat. Since existing survey protocol has an unknown effect on spider habitat and populations, regular monitoring is difficult and assessment of recovery is limited (USFWS 1998, 2014). Therefore, our objective was to conduct a study of bryophyte-mat removal to determine reestablishment and desiccations rates up to 1 year post-survey. We designed an experimental study to compare control and treatment plots to determine if treatments would influence attachment rates. Our results would help determine if bryophyte mat surveys cause long-term damage to suitable Spruce-fir Moss Spider habitat. This work would also allow for recommendations on time between surveys at a site, as well as indicating what other factors (e.g., bryophyte type, treatment type) would affect post-survey mat-recovery time.

\section{Field-site Description}

We conducted our study in montane spruce-fir forests in the Blue Ridge subphysiographic province of the southern Appalachian Mountains in western North 
Carolina. We established bryophyte-removal plots in the Roan Mountain Highlands, Pisgah National Forest, Mitchell County, NC (36 $\left.6.26^{\prime} \mathrm{N}, 82^{\circ} 7.70^{\prime} \mathrm{W}\right)$. We selected 2 study areas in the western part of the Roan Mountain Highlands. These 2 study areas varied in elevation from 1880 to $1895 \mathrm{~m}$, had northwest aspects, and were located $0.1 \mathrm{~km}$ away from each other. We selected these 2 study areas because 2 stable populations of Spruce-fir Moss Spiders existed at these sites, there were large amounts of suitable habitat relative to other locations, and the habitat was representative of habitat in other parts of the species' range. Spruce-fir Moss Spider habitat was typically found on rock outcrops along north-facing aspects, since habitat on those aspects was more mesic. The spider's habitat was rarely found on southern aspects; therefore, we did not select sites on those aspects due to lack of suitable habitat. We did not select more survey areas because we did not want to disturb the habitat of smaller populations for this experiment. Because known populations of Spruce-fir Moss Spider occur at our 2 study areas, the exact locations of the areas are not disclosed to protect this endangered species. The Roan Mountain Highlands has mild summers and cold winters (average temperatures of $15-30{ }^{\circ} \mathrm{C}$ and $-4-16{ }^{\circ} \mathrm{C}$, respectively), with high amounts of annual precipitation (150-200 $\mathrm{cm}$ ) and low cloud deposition (50-75\% of the year) (Berry and Smith 2012, 2013; $\mathrm{McNab}$ and Avers 1994).

\section{Methods}

To select random sites, we used geospatial data of known rock outcrops across a 5.5-ha area at study area A and a 6-ha area at study area B. In June 2017, we established sites in known spider habitat at the 2 study areas. Since the size of each rock outcrop varied drastically, we randomly placed 1-2 sites on individual emergent rock outcrops or boulders with appropriate bryophyte habitat (15 sites in study area A, 15 in study area B). Our reasoning was two-fold: (1) the bryophyte species the spider is known to occur under are not typically found on all rock surfaces and tend to be a patchy resource, and (2) we wanted to spread sites over a larger area to avoid heavily impacting 1 or 2 rock outcrops in the event our surveys had negative impacts on bryophyte reattachment. Coyle (2004) recommended not surveying all suitable habitat on a given rock outcrop for that reason and to avoid needlessly eliminating spider habitat at a site. Each site was separated by $\geq 5 \mathrm{~m}(24.5 \pm 3.0 \mathrm{SE}$, $\min -\max =5.0-62.7)$ and was composed of one of 3 bryophyte types: 2 moss types (Dicranodontium/Dicranum spp. or Polytrichum spp.) and a liverwort type (Bazzania spp.). We did not distinguish between Dicranodontium spp. and Dicranum spp. species due to difficulty differentiating the genera in the field and hereafter refer to this group as "Dicranoids". Additionally, we did not identify mosses or liverworts to species since bryophyte genus was the indicating factor for appropriate spider habitat in past surveys. At each site, we placed two $10 \mathrm{~cm}$ x $10 \mathrm{~cm}$ plots spaced $0.5 \mathrm{~m}$ apart. Both plots at a site were in the same bryophyte type. At each site, we assigned a control plot $(n=30)$ and a treatment plot $(n=30)$. Control plots were given no treatment after we replaced the bryophyte mat on the rock. For treatment 
plots, we misted (sprayed 4-5 times with water from a $12 \mathrm{oz}$ spray bottle) the top of the bryophyte mat after replacement on the rock. We selected water application as a treatment to see if adding moisture after reattaching the moss helped with long-term mat recovery.

At each plot, we demarcated the plot with a malleable $10 \mathrm{~cm} \times 10 \mathrm{~cm}$ frame made of 24-gauge, galvanized steel wire. We recorded the bryophyte type, the slope of the plot $\left(0^{\circ}-90^{\circ}\right)$, and measured bryophyte mat depth to the rock surface at 4 points in the plot. We removed $10 \mathrm{~cm} \times 10 \mathrm{~cm}$ bryophyte mats at each plot site by cutting the mat down to the rock on three sides of the plot frame with a knife, keeping the bottom portion of the bryophyte mat attached to the rock so we could peel down the mat to mimic the bryophyte removal technique surveyors would use to search for spiders. Coyle $(1997,1999,2004,2009)$ used this technique during past surveys, so potential spiders under the bryophyte mat would not fall on the ground, but would be caught at the bottom of where the mat remained attached to the rock.

To be able to identify the exact location of a bryophyte plot in order to evaluate reattachment rates during later surveys, we attached a weatherproof vinyl tag with plot information, including plot type, on the $10 \mathrm{~cm} \times 10 \mathrm{~cm}$ frame. We replaced the bryophyte mats directly back on the rock surface, pressing the metal frame into the rock so it would take the rock's shape and stay in place. We applied the treatments after replacing each mat onto the rock's surface. We only treated mats a single time immediately after the initial removal and did not remove or retreat them henceforth. We recorded the dominant overstory trees and estimated canopy cover directly above each plot using a spherical densiometer.

To assess the short- and long-term efficacy of these surveys, we monitored plots in July 2017, November 2017, and June 2018. We selected these times because we wanted to determine the effects of bryophyte removal on plots at different timescales: 1 month post-removal, pre-winter condition, and condition 1 year after establishment. During visits to sites, we did not re-remove bryophyte mats in plots to determine attachment and condition or reapply treatments. Instead, we gently tugged at different parts of the bryophyte mats to determine if mats were reattaching to the adjacent bryophyte mats and the rock, and to evaluate the extent of mat reattachment. We also assessed the condition of the bryophyte mat at each plot by determining the percentage of the bryophyte mat that was desiccated, as indicated by yellow/brown coloration. We did not consider mats with yellow/brown color (i.e., chlorotic) as dead since bryophytes can survive desiccation and rejuvenation several weeks to years after the desiccation event (Glime 2017). Additionally, we were able to judge desiccation and color of bryophytes in our plots by comparing the plots to adjacent moss patches that experience the same microclimate conditions as the moss plots. However, desiccated bryophytes are more likely to fall off a rock and indicate poor habitat conditions for the Spruce-fir Moss Spider (i.e., Coyle 2004). We then ranked plots from 0 to 10 , where $0=$ bryophyte mat is completely reattached and $100 \%$ alive (e.g., green in color), while $10=$ bryophyte mat was completely unattached from the rock, had $100 \%$ desiccation, and were chlorotic since the last visit to the plot (Table 1). 
We used a generalized linear binomial distribution model (PROC GENMOD) in SAS 9.4 (SAS Institute, Cary, NC) to determine impacts of treatment type, bryophyte type, plot slope, average bryophyte mat depth, and overstory canopy cover over 3 site re-visits on reattachment rates. This model allowed for unbalanced sample sizes, which was suitable for our dataset because it was difficult to survey an even number of sites in each bryophyte type as they widely varied in their frequency and distribution in our study areas. We analyzed the impact of treatments over time using our model on attachment rankings from the final visit with treatment type (control as reference condition) and bryophyte type (Bazzania as reference condition) as fixed effects and the other variables as random effects. We did not use study area as a covariate in our model because the 2 study areas were at similar elevations and aspects, and occurred close together on the same mountain. We used a priori planned contrasts to examine treatment-type (control versus treatment) and bryophyte-type effects on reattachment rates.

\section{Results}

Overall, we surveyed 60 plots: 26 Dicranoids, 22 Bazzania spp., and 12 Polytrichum spp. One year after bryophyte mat disturbance on our final visit, we found $60 \%$ of plots $100 \%$ alive and completely or mostly reattached to the rock surface $(33.3 \%$ $=$ ranking $0,26.7 \%=$ ranking 1 ). Approximately $15 \%$ of plots were $100 \%$ alive without reattaching to the rock (ranking 2 to 3 ). A total of $10 \%$ of plots varied in their reattachment, had partial desiccation, and were chlorotic (ranking 4 to 9), whereas $15 \%$ had fully desiccated and had completely fallen off the rock (ranking 10). Of the bryophyte mats that completely fell off the rock (ranking 10 ), $66.7 \%$ were on rock slopes $>80^{\circ}$. However, these plots only accounted for $24 \%$ of all plots that were on

Table 1. Bryophyte-mat reestablishment rankings for removal study in Spruce-fir Moss Spider (Microhexura montivaga) habitat at Roan Mountain Highlands, Mitchell County, NC, 2017-2018. We ranked plots based on bryophyte desiccation, chlorotic condition, and reattachment to rock surface. We ranked bryophyte desiccation and chlorotic condition higher than reattachment since these mats may be unlikely to reattach, especially if conditions within a plot were poor compared to surrounding bryophyte mats. Partially reattached $=25-75 \%$ reattached. Partially off rock $=>10 \%$ off rock. A ranking of 10 indicated $100 \%$ desiccation and chlorotic condition, or the moss mat had completely unattached from the rock.

\begin{tabular}{lcl} 
Ranking & Bryophyte desiccation/chlorotic condition & \multicolumn{1}{c}{ Reattachment } \\
\hline 0 & $0 \%$ & Completely reattached \\
1 & $0 \%$ & Partially reattached \\
2 & $0 \%$ & Not reattached but holding position \\
3 & $0 \%$ & Not reattached and partially off rock \\
4 & $<50 \%$ & Partially reattached \\
5 & $<50 \%$ & Not reattached but holding position \\
6 & $<50 \%$ & Not reattached and partially off rock \\
7 & $>50 \%$ & Partially reattached \\
8 & $>50 \%$ & Not reattached but holding position \\
9 & $>50 \%$ & Not reattached and partially off rock \\
10 & $100 \%$ & Not reattached or completely off rock \\
\hline
\end{tabular}


rock slopes $>80^{\circ}$, whereas $50 \%$ of plots at these steeper slopes had reattached to the rock without any desiccation (ranking $0-1$ ). Our results showed that only plot slope negatively impacted long-term reattachment rates (Table 2, Fig. 1). Additionally, probability of reattachment 1 month post-removal was similar to probability of

Table 2. Results of the generalized linear binomial distribution model for the study of Spruce-fir Moss Spider (Microhexura montivaga) bryophyte-mat reestablishment at the Roan Mountain Highlands, Mitchell County, NC, 2017-2018.

\begin{tabular}{|c|c|c|c|c|c|c|c|}
\hline \multirow{2}{*}{$\frac{\text { Parameter }}{\text { Intercept }}$} & \multirow{2}{*}{$\frac{\mathrm{DF}}{1}$} & \multirow{2}{*}{$\begin{array}{r}\text { Estimate } \\
6.8558\end{array}$} & \multirow{2}{*}{$\begin{array}{c}\begin{array}{c}\text { Standard } \\
\text { error }\end{array} \\
4.3442\end{array}$} & \multicolumn{2}{|c|}{$\begin{array}{c}\text { Wald } 95 \% \\
\text { confidence limits }\end{array}$} & \multirow{2}{*}{$\frac{\text { Wald } \chi^{2}}{1.58}$} & \multirow{2}{*}{$\begin{array}{c}P \\
0.1145\end{array}$} \\
\hline & & & & -1.6587 & 15.3704 & & \\
\hline Visit & & -0.0514 & 0.2248 & -0.4919 & 0.3891 & -0.23 & 0.8191 \\
\hline Treatment & 1 & -0.1222 & 0.4773 & -1.0576 & 0.8132 & -0.26 & 0.7979 \\
\hline Control $^{1}$ & 0 & 0.0000 & 0.0000 & 0.0000 & 0.0000 & - & - \\
\hline Polytrichum spp. & 1 & 1.2456 & 0.5892 & 0.0908 & 2.4005 & 2.11 & 0.0345 \\
\hline Dicranoid & 1 & -0.3933 & 0.7294 & -1.8229 & 1.0364 & -0.54 & 0.5898 \\
\hline Bazzania spp. ${ }^{1}$ & 0 & 0.0000 & 0.0000 & 0.0000 & 0.0000 & - & - \\
\hline Slope (deg) & 1 & -0.0324 & 0.0116 & -0.0550 & -0.0097 & -2.8 & 0.0051 \\
\hline Depth $(\mathrm{cm})$ & 1 & -0.1127 & 0.1680 & -0.4421 & 0.2166 & -0.67 & 0.5023 \\
\hline Canopy (\%) & 1 & -0.0371 & 0.0447 & -0.1247 & 0.0504 & -0.83 & 0.4059 \\
\hline
\end{tabular}

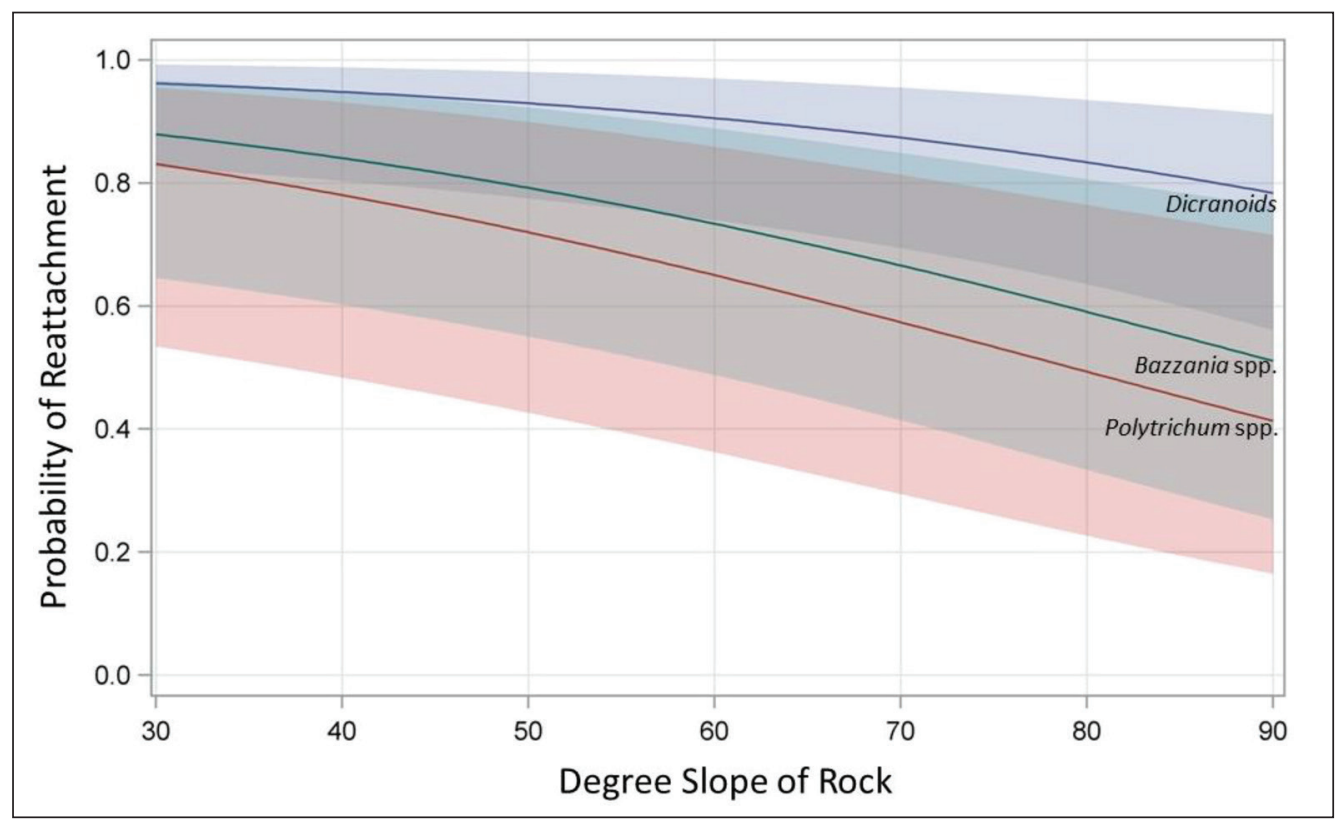

Figure 1. Reattachment probability of $10 \mathrm{~cm} \times 10 \mathrm{~cm}$ bryophyte-mat plots 1 year postremoval in Spruce-fir Moss Spider (Microhexura montivaga) habitat in the Roan Mountain Highlands, Mitchell County, NC. Conditions were measured during bryophyte removal and replacement in June 2017 and compared to conditions in June 2018. Reattachment probability is relative to degree slope of rock surface. All 3 bryophyte types are indicated with labeled lines, and colored bands represent confidence intervals. 
reattachment after several months and 1 year post-removal. There was no significant difference between the control and water treatment at any point in the study. Reattachment did differ by moss type with Dicranoids showing higher attachment rates than Bazzania $(P=0.03)$ and Polytrichum $(P=0.05)$ (Fig. 1$)$.

\section{Discussion}

We found that most bryophyte mats reattached to the rock surface 1 year after removal, highlighting the feasibility of this technique to monitor Spruce-fir Moss Spider populations without causing long-term damage to their habitat. Probability of attachment did not vary drastically over time, indicating that mat assessments 1 month post-survey would most likely indicate the bryophyte mat's condition after 1 year post-removal. Although we found that most of the bryophyte mats completely or mostly reattached to the rock with no mat desiccation and were not chlorotic, $\sim 24 \%$ had some level of prolonged desiccation and did not completely reattach or had completely fallen. Rock slope negatively influenced reattachment rates with steeper slopes resulting in a higher probability the bryophyte mat would fall off. Additionally, there were different reattachment rates depending on bryophyte type, suggesting that Dicranoid mosses are more vulnerable than Bazzania or Polytrichum to disturbance. Other factors, such as bryophyte depth and canopy cover, did not have any impact on reestablishment rates. This result is probably because at all sites canopy cover was high (80-95\%) and bryophyte depth would be considered suitable for the spider, which avoids very thin and very thick mats (Coyle 2009).

Bryophyte mats in both the treatment and control plots had better immediate attachment rates and maintained attachment to the rock surface over time, with no significant differences between the treatment and control plots. Therefore, our results indicated that post-removal application of water is not needed to increase attachment rates. We would caution that our survey only occurred over the course of 1 year, and fluctuations in precipitation during droughts may require a water treatment to increase attachment rates, but more work is needed to confirm this hypothesis since our survey took place in a non-drought year. While treatment did not influence attachment rates after 1 year, relatively steeper rock slopes negatively impacted reattachment rates. Steeper rock slopes are difficult to avoid during Spruce-fir Moss Spider surveys because well-drained bryophyte mats tend to be on sloping rocks (Coyle 1997). Occasionally, we found that our surveyed mats were difficult to reposition on a vertical surface (i.e., $>80 \%$ slope). In such instances, successful reattachment may frequently not occur after a survey, making the probability of long-term reestablishment of the bryophyte mat less likely (Coyle 2009). Weather, such as heavy fog and rain, may negatively influence reestablishment rates (Allen 2017), especially immediately following surveys on steeper-sloped rocks. Therefore, though steeper surfaces may need to be surveyed since spiders are known to occur in these habitats (Coyle 2009), we caution that handling bryophyte mats at such sites should be done carefully.

If a Spruce-fir Moss Spider is located on a mat that does not reestablish, individuals have to relocate to another suitable site. Relocation may potentially jeopardize 
spider survival as movement and dispersal rates are believed to be low due to patchy habitat distributed among highly disjunct populations (Coyle 2009, Hedin et al. 2015). Previous research found that surveyed rock outcrops had noticeably fewer patches of bryophyte mats for up to a decade later, although total mat loss was not quantified (Coyle 2004, 2009). During our study, we only removed $10 \mathrm{~cm}$ x $10 \mathrm{~cm}$ patches, which may be smaller than those removed by Harp $(1991,1992)$ and Coyle $(1997,1999,2004,2009)$ during their surveys, wherein the size of mats removed were unspecified. Additionally, we did not separate the moss patches into smaller pieces, which was a method used by Coyle during his surveys. Separating the bryophyte mats into smaller pieces improved detection of spiders, but made replacing bryophyte mats back on the rock very difficult (Coyle 2004). Because the impacts of surveys may be seen for years post-survey, it is important to temporally and spatially separate surveys. We conservatively recommend a minimum of 2 years between spider surveys at the same rock outcrop to allow bryophyte mats to reestablish in areas that experience partial desiccation post-survey.

Lack of reestablishment may lead to bare rock in an area that was once covered with bryophytes. We observed that $15 \%$ of our plots never reestablished (a total of $90 \mathrm{~cm}^{2}$ of suitable habitat), which may impact long-term bryophyte species composition at a site. While bryophyte mats on rocks surfaces evolved with disturbances such as animal activity or gravity-induced sloughing of heavy mats, natural disturbance rates are typically very low, and larger or more frequent disturbances may prolong recovery of the mats (Studlar and Peck 2007). Bryophyte habitat on steep or vertically sloped rock surfaces may represent a climax community, although over long periods of time these communities show cyclical succession where natural sloughing of mats exposes bare rock, bryophytes reestablish, grow and become heavy, leading to sloughing again (Smith 1982). The successional dynamics of bryophyte communities on rocky outcrops in spruce-fir forests in the region are not well known (but see Stehn et al. 2010b). Spider surveys may shift community successional trajectories depending on intensity and frequency of surveys and their subsequent reestablishment rates, potentially similar to shifts seen in commercial moss harvesting (Peck and Frelich 2008, Studlar and Peck 2007).

It is unknown whether the removal of bryophyte mats during surveys modifies bryophyte species composition or impacts other invertebrate species living within the bryophyte mats, though it seems likely that failed reestablishment or desiccation would have negative impacts on the bryophyte mat ecosystem. Southern Appalachian spruce-fir forests also have a high diversity of bryophyte species, and $\sim 44$ species occur on rock outcrops or boulders (Norris 1974, Stehn et al. 2010b). Bazzania nudicaulis (Evans) is a globally imperiled liverwort endemic to southern Appalachian spruce-fir forests and can be found in bryophyte mats on rock outcrops (Stehn et al. 2010b). Bazzania spp. are commonly found on bryophyte mats with detections of Spruce-fir Moss Spider (Coyle 2004), therefore B. nudicaulis could be impacted by surveys especially in cases where mats do not reattach. Additionally, bryophyte mats on rocky outcrops are home to many species of invertebrates, and some species are obligate on these environments (Gerson 1982), although the status and composition of invertebrates found in these types of communities are typically 
understudied (Main 2000). Further work needs to be conducted to determine the impacts of surveys for spiders within bryophyte mats on other flora and fauna within the southern Appalachians.

Changes in canopy cover might interact with survey impacts to alter or reduce the bryophyte community at a site. High-elevation bryophyte communities may be resistant to under-canopy climatic changes in natural canopy gaps (Berdugo and Dovciak 2019), but larger overstory disturbances from BWA may cause conditions outside the tolerance of bryophyte communities situated on rocky substrate. Open canopies from BWA and large windthrow events are known to decrease the probability of finding the Spruce-fir Moss Spider (Coyle 2009, Roble 2012). Overstory cover at all of our sites was high; therefore, the bryophyte reestablishment rates observed during our study were under shaded conditions. We purposely worked in areas of high canopy cover because previous spider surveys in areas with BWA overstory kill resulted in no detections due to bryophyte desiccation (Coyle 1994, 2009). Bryophyte establishment rates may have been different in areas of BWA infestation or areas of large windthrow events. Since bryophyte communities are affected by canopy gaps due to BWA (Stehn et al. 2010b) and single-tree fall and windthrow events are common in spruce-fir forests (Rentch et al. 2010, White et al. 1985), permanent survey plots would help determine the potential impacts of these forest dynamics on Spruce-fir Moss Spider populations and their associated habitat.

Future forest management efforts to increase resiliency to climate change in spruce-fir forests should be accompanied by long-term monitoring of the Sprucefir Moss Spider habitat. There is growing interest in the ecological restoration of spruce-fir forests in the southern Appalachians due to these forest's ecological, economic, and recreational value (Jenkins et al. 2002, Potter et al. 2005), as well as the importance of this forest type to rare and endemic species (Diggins et al. 2017, Milling et al. 1997, Rossell et al. 2018, Ulrey et al. 2016, Wheeler and McHugh 1994). The use of canopy-gap creation to mimic natural disturbances and release understory spruce is the primary silvicultural treatment to restore these forests (Rentch et al. 2007, 2016). Bryophyte communities may be adapted to natural canopy-gap dynamics in high-elevation conifer forests (Berdugo and Dovciak 2019, Stehn et al. 2010b). Since more species-specific information on the bryophyte community would be needed to determine long-term impacts of spider surveys on successional dynamics of their habitat, we recommend a bryologist be consulted on future monitoring projects. Finally, long-term monitoring using surveys of bryophyte mats will help determine how spider surveys impact long-term successional dynamics of bryophyte mats and if ecological restoration treatments or anthropogenic impacts (e.g., climate change, BWA infestation) negatively impact populations and the critical habitat of the Spruce-fir Moss Spider.

\section{Acknowledgments}

We thank Sue Cameron, Fred Coyle, Sheryl Bryan, and Gary Kauffman for their assistance and thoughtful insight over the duration of this project. Foster Levy, Andrew Landsman, and two anonymous reviewers provided comments that improved this 
manuscript. This research was funded by the US Fish and Wildlife Service Asheville Field Office (FWS Agreement \#4500085700). Any use of trade, firm, or product names is for descriptive purposes only and does not imply endorsement by the US Government. All work was conducted under US Fish and Wildlife Service Endangered and Threatened Wildlife Permit \#YE34778A-2. The authors declare no conflicts of interest relating to this work.

\section{Literature Cited}

Allen, J.L. 2017. Testing lichen transplant methods for conservation applications in the southern Appalachian Mountains, North Carolina, USA. Bryologist 120:311-319.

Andrew, N.R., L. Rodgerson, and M. Dunlop. 2003. Variation in invertebrate-bryophyte community structure at different spatial scales along altitudinal gradients. Journal of Biogeography 30:731-746.

Banks, S.A. 2013. Forest response to the U.S. 1990 Clean Air Act: The southern spruce-fir ecosystem. M.Sc. Thesis. North Carolina State University, Raleigh, NC. 49 pp.

Barata, I.M., R.A. Griffiths, and M.S. Ridout. 2017. The power of monitoring: Optimizing survey designs to detect occupancy changes in a rare amphibian population. Scientific Reports 7:16491.

Berdugo, M.B., and M. Dovciak. 2019. Bryophytes in fir waves: Forest-canopy indicator species and functional diversity decline in canopy gaps. Journal of Vegetation Science 30:235-246.

Berry Z.C., and W.K. Smith. 2012. Cloud pattern and water relations in Picea rubens and Abies fraseri, southern Appalachian Mountains, USA. Agricultural and Forest Meteorology 162:27-34.

Berry Z.C., and W.K. Smith. 2013. Ecophysiological importance of cloud immersion in a relic spruce-fir forest at elevational limits, southern Appalachian Mountains, USA. Oecologia 173:637-648.

Campbell, S.P., J.A. Clark, L.H. Crampton, A.D. Guerry, L.T. Hatch, P.R. Hosseini, J.J. Lawler, and R.J. O'Connor. 2002. An assessment of monitoring efforts in endangered species recovery plans. Ecological Applications 12:674-681.

Coyle, F.A. 1981. The mygalomorph spider genus Microhexura (Araneae, Dipluridae). Bulletin of the American Museum of Naturalist History 170:64-75.

Coyle, F.A. 1997. Status survey of the endangered Spruce-fir Moss Spider, Microhexura montivaga Crosby \& Bishop, on Mount LeConte. Report to the US Fish and Wildlife Service, Asheville, NC. 20 pp.

Coyle, F.A. 1999. Status survey of the endangered Spruce-fir Moss Spider, Microhexura montivaga Crosby \& Bishop, on Roan Mountain. Report to the US Fish and Wildlife Service and the US Forest Service, Asheville, NC. 9 pp.

Coyle, F.A. 2004. Status survey of the endangered Spruce-fir Moss Spider, Microhexura montivaga in the Great Smoky Mountains National Park. Report to the Great Smoky Mountains National Park, Asheville, NC. 24 pp.

Coyle, F.A. 2009. Status survey of the Spruce-fir Moss Spider, Microhexura montivaga. Report to the US Fish and Wildlife Service, Asheville, NC. 22 pp.

Culatta, K.E., and J.L. Horton. 2014. Physiological response of southern Appalachian highelevation rock outcrop herbs to reduced cloud immersion. Castanea 79:182-194.

Diggins, C.A., L.M. Gilley, C.A. Kelly, and W.M. Ford. 2016. Comparison of survey techniques on detection of Northern Flying Squirrels. Wildlife Society Bulletin 40:654-662.

Diggins, C.A., L.M. Gilley, C.A. Kelly, and W.M. Ford. 2017. Home range, den selection, and habitat use of Carolina Northern Flying Squirrels (Glaucomys sabrinus coloratus). Wildlife Research 44:427-437. 
Dillard, L.O., K.R. Russell, and W.M. Ford. 2008. Site-level habitat models for the endemic, threatened Cheat Mountain Salamander (Plethodon nettingi): The importance of geophysical and biotic attributes for predicting occurrence. Biodiversity Conservation 17:1475-1492.

Dull, C.W., J.D. Ward, H.D. Brown, G. W. Ryan, W.H. Clerke, and R. J. Uhler. 1988. Evaluation of spruce and fir mortality in the southern Appalachian Mountains. Technical Paper R-8-PR13. US Forest Service Southern Region Research, Atlanta, GA. 86 pp.

Eagar, C., and M.B. Adams. 1992. Ecology and Decline of Red Spruce in the Eastern United States. Springer-Verlag, New York, NY. 417 pp.

Edworthy, A.B., K.M.M. Steensma, H.M. Zandberg, and P.L. Lilley. 2012. Dispersal, home-range size, and habitat use of an endangered land snail, the Oregon Forest Snail (Allogona townsendiana). Canadian Journal of Zoology 90:875-884.

Fridell, J.A. 1995. Endangered and threatened wildlife and plants: Spruce-fir Moss Spider determined to be endangered. Federal Register 60(24):6968-6973.

Gerson, U. 1982. Bryophytes and invertebrates. Pp. 291-332, In A.J.E. Smith (Ed.). Bryophyte Ecology. Chapman and Hall, London, UK. 511 pp.

Glime, J.M. 2017. Bryophyte Ecology, Volume 1: Physiological Ecology. Michigan Technological University. Available online at http://digitalcommons.mtu.edu/bryophyteecology/.. Accessed 8 October 2020.

Halpern, C.B., M. Dovčiak, L.S. Urgenson, and S.A. Evans. 2014. Substrates mediate responses of forest bryophytes to a gradient in overstory retention. Canadian Journal of Forest Research 44:855-866.

Harp, J.M. 1991. Status report on the "Spruce-fir Moss Spider", Microhexura montivaga Crosby and Bishop, in the Great Smoky Mountains National Park. Report to the National Park Service, US Department of the Interior, Gatlinburg, TN. 13 pp.

Harp, J.M. 1992. A status survey for the Spruce-fir Moss Spider, Microhexura montivaga Crosby and Bishop (Araneae, Dipluridae). Report to the North Carolina Wildlife Resources Commission, Raleigh, NC. 31 pp.

Hedin, M., D. Carlson, and F. Coyle. 2015. Sky island diversification meets the multispecies coalescent: Divergence in the Spruce-fir Moss Spider (Microhexura monitvaga, Araneae, Mygalomorphae) on the highest peaks of southern Appalachia. Molecular Ecology 24:3467-3484.

Horton J.L., and K.E. Culatta. 2016. Physiological characteristics of southern Appalachian high-elevation rock outcrop herbs on clear and cloudy days. Castanea 81:270-279.

Jenkins, D.H., J. Sullivan, G.S. Amacher, N.S. Nicholas, and D.X. Reaves. 2002. Valuing high altitude spruce-fir forest improvements: Importance of forest condition and recreation activity. Journal of Forest Economics 8:77-99.

Johnson, D.M., and W.K. Smith. 2008. Cloud immersion alters microclimate, photosynthesis, and water relations in Rhododendron catawbiense and Abies fraseri seedlings in the southern Appalachian Mountains, USA. Tree Physiology 28:385-392.

Kaylor, S., J. Hughes, and J.A. Franklin. 2017. Recovery trends and predictions of Frasier Fir (Abies fraseri) dynamics in the southern Appalachian Mountains. Canadian Journal of Forest Research 47:125-133.

Koo, K.A., B.C. Patten, and M. Madden. 2015. Predicting effects of climate change on habitat suitability of Red Spruce (Picea rubens Sarg.) in the southern Appalachian Mountains of the USA: Understanding complex system mechanisms through modeling. Forests 6:1208-1226.

Korstian, C.F. 1937. Perpetuation of spruce on cut-over and burned lands in the higher Southern Appalachian Mountains. Ecological Monographs 7: 125-167. 
Lindo, Z., and N. Winchester. 2013. Out on a limb: Microarthropod and microclimate variation in coastal temperate rainforest canopies. Insect Conservation and Diversity 6:513-521.

Main, B.Y. 2000. Habitat template for invertebrates on granite outcrops. Journal of the Royal Society of Western Australia 83:139-147.

Mathias, J.M., and R.B. Thomas. 2018. Disentangling the effects of acidic air pollution, atmospheric CO2, and climate change on recent growth of Red Spruce trees in the central Appalachian Mountains. Global Change Biology 24:3938-3953.

McNab, W.H., and P.E. Avers. 1994. Ecological subregions of the United States: Section descriptions. US Forest Service Administration Publication WO-WSA-5. US Department of Agriculture, Washington, DC. $267 \mathrm{pp}$.

Milling, T.C., M.P. Rowe, B.L. Cockerel, T.A. Dellinger, J.B. Gailes, and C.E. Hill. 1997. Population densities of Northern Saw-whet Owls (Aegolius acadicus) in degraded boreal forests of the southern Appalachians. Pp. 272-285, In J.R. Duncan, D.H. Johnson, and T.H. Nicholls (Eds.). Biology and Conservation of Owls of the Northern Hemisphere: $2^{\text {nd }}$ International Symposium. General Technical Report NC-190, North Central Forest Experiment Station, Forest Service, US Department of Agriculture, St. Paul, MN. 653 pp.

Nelson, C.R., and C.B. Halpern. 2005. Short-term effects of timber harvest and forest edges on ground-layer mosses and liverworts. Canadian Journal of Botany 83:610-620.

Nicholas, N.S., and S.M. Zedaker. 1989. Ice damage in spruce-fir forests of the Black Mountains, North Carolina. Canadian Journal of Forest Research 19:1487-1491.

Norris, D.H. 1974. Bryoecology of the Appalachian spruce-fir zone. Ph.D. Dissertation. University of Tennessee, Knoxville, TN. 187 pp.

Noss, R.F., E.T. LaRoe, and J.M. Scott. 1995. Endangered ecosystems of the United States: A preliminary assessment of loss and degradation. Biological Report 28. US National Biological Service, Washington, DC. 95 pp.

Peck, J.E., and L.E. Frelich. 2008. Moss harvest truncates the successional development of epiphytic bryophytes in the Pacific Northwest. Ecological Applications 18:146-158.

Potter, K.M., J. Frampton, J. Sidebottom, B. Onken, and R. Reardon. 2005. Impacts of Balsam Woolly Adelgid on the southern Appalachian spruce-fir ecosystem and the North Carolina Christmas tree industry. Pp. 25-41, In B. Onken, and R. Reardon (Eds.). Proceedings of the Third Symposium on Hemlock Woolly Adelgid in the Eastern United States. US Forest Service, Asheville, NC. 398 pp.

Proctor, M.C.F. 2000. Physiological ecology. Pp. 225-247, In A.J. Shaw, and B. Goffinet (Eds.). Bryophyte Biology. Cambridge University Press, Cambridge, UK. 486 pp.

Rabinowitz, D., S. Cairns, and T. Dillon. 1986. Seven forms of rarity and their frequency in the flora of the British Isles. Pp. 182-204, In M. E. Soule (Ed.). Conservation Biology: The Science of Scarcity and Diversity. Sinauer, Sunderland, MA. 598 pp.

Rentch, J.S., T.M. Schuler, W.M. Ford, and G.J. Nowacki. 2007. Red Spruce stand dynamics, simulations, and restoration opportunities in the central Appalachians. Restoration Ecology 15:440-452.

Rentch, J.S., T.M. Schuler, G.J. Nowacki, N.R. Beane, and W.M. Ford. 2010. Canopy-gap dynamics of second growth Red Spruce-northern hardwood stands in West Virginia. Forest Ecology and Management 260:1921-1929.

Rentch, J.S., W.M. Ford, T.S. Schuler, J. Palmer, and C.A. Diggins. 2016. Release of suppressed Red Spruce using canopy gap creation: Ecological restoration in the central Appalachians. Natural Areas Journal 36:29-37.

Richardson, A.D., E.G. Denny, T.G. Siccama, and X. Lee. 2003. Evidence for a rising cloud ceiling in eastern North America. Journal of Climate 16:2093-2098. 
Roble, S.M. 2012. Status survey for the Spruce-fir Moss Spider (Microhexura montivaga) in Virginia. Final Report to the Virginia Department of Game and Inland Fisheries, Richmond, VA. 19 pp.

Rossell, C.R., I.C. Haas, L.A. Williams, and S.C. Patch. 2018. Comparison of relative abundance and microhabitat of Desmognathus organi (Northern Pygmy Salamander) and Desmognathus wrighti (Southern Pygmy Salamander) in North Carolina. Southeastern Naturalist 17:141-154.

Schori, J.C., T.E. Steeves, and T.J. Murray. 2020. Informing the design of a long-term population density monitoring protocol for a nationally endangered grasshopper: Removal sampling as basis for estimating individual detection probabilities. Journal of Insect Conservation 24:841-851.

Seaborn, T., and K. Catley. 2016. Abiotic microhabitat parameters of the Spruce-fir Moss Spider, Microhexura monitvaga Crosby and Bishop (Araneae: Dipluridae). Southeastern Naturalist 15:16-75.

Smallwood, K.S., J. Beyea, and M.L. Morrison. 1999. Using the best scientific data for endangered species conservation. Environmental Management 23:421-435.

Smith, A.J.E. 1982. Epiphytes and epiliths. Pp. 191-228, In A.J.E. Smith, (Ed). Bryophyte Ecology. Chapman and Hall, London, UK. 511 pp.

Smith, G.F., and N.S. Nicholas. 1998. Patterns of overstory composition in fir and firspruce forests of the Great Smoky Mountains after Balsam Woolly Adelgid infestation. American Midland Naturalist 139:340-352.

Stehn, S.E., C.R. Webster, J.M. Glime, and M.A. Jenkins. 2010a. Elevation gradients of bryophyte diversity, life forms, and community assemblage in the southern Appalachian Mountains. Canadian Journal of Forest Research 40:2164-2174.

Stehn, S.E., C.R. Webster, J.M. Glime, and M.A. Jenkins. 2010b. Ground-layer bryophyte communities of post-adelgid Picea-Abies forests. Southeastern Naturalist 9:435-452.

Studlar, S.M., and J.E. Peck. 2007. Commercial moss harvest in the Appalachian Mountains of West Virginia: Targeted species and incidental take. Bryologist 110:752-765.

Ulrey, C., P.F. Quintana-Ascencio, G. Kauffman, A.B. Smith, and E.S. Menges. 2016. Life at the top: Long-term demography, microclimate refugia, and responses to climate change for a high-elevation southern Appalachian endemic plant. Biological Conservation 200:80-92.

US Fish and Wildlife Service (USFWS). 1998. Recovery Plan for the Spruce-fir Moss Spider. Atlanta, GA. 22 pp.

USFWS. 2001. Endangered and threatened wildlife and plants; designation of critical habitat for the Spruce-fir Moss Spider. Federal Register 50 CFR Part 17 66(130):35547-35566.

USFWS. 2014. Spruce-fir Moss Spider (Microhexura montivaga) 5-Year Review: Summary and Evaluation. US Fish and Wildlife Service Report, Ashville Ecological Service Field Office, Southeast Region, Asheville, NC. 20 pp.

Walter, J.A., J.C. Neblett, J.W. Atkins, and H.E. Epstein. 2017. Regional- and watershedscale analysis of Red Spruce habitat in the southeastern United States: Implications for future restoration efforts. Plant Ecology 218:305-316.

Wehner, K., M. Heethoff, and A. Brückner. 2018. Seasonal fluctuation of oribatid mite communities in forest microhabitats. PeerJ 6:e4863.

Wheeler, Q.D., and J.V. McHugh. 1994. A new southern Appalachian species, Dasycerus bicolor (Coleoptera:Staphylinidae:Dasycrinae), from declining endemic fir forests. Coleopterists Bulletin 48:265-271. 
White, P.B., P. Soulé, and S. van de Gevel. 2014. Impacts of human disturbance on the temporal stability of climate-growth relationships in a Red Spruce forest, southern Appalachian Mountains, USA. Dendrochronologia 32:71-77.

White, P.S., M.D. MacKenzie, and R.T. Busing. 1985. Natural disturbance and gap-phase dynamics in southern Appalachian spruce-fir forests. Canadian Journal of Forest Research 15:233-240.

Yanoviak, S.P., N.M. Nadkarni, and R. Solano. 2007. Arthropod assemblages in epiphyte mats of Costa Rican cloud forests. Biotropica 39:202-210. 